\title{
Вплив фізичної реабілітації засобами ерготерапії на пацієнтів 3 різними видами полінейропатії
}

\author{
УдК 616.89.-008.441.3:616-071.4 \\ О. В. Баскевич \\ Прикарпатський національний університет імені Василя Стефаника,
Ївано-Франківськ, Україна
}

\begin{abstract}
Анотація. Мета. Виявити основні фактори, що впливають на якість життя й електрофізіологічні прояви алкогольної полінейропатії та їх зміни після застосування методів ерго- і фізичної терапії. Методи. Аналіз спеціальної науково-методичної літератури, клініко-лабораторні та соціологічні методи, параметрична і непараметрична статистика. Висновки. Між клінічними проявами алкогольної полінейропатії, асиметричним пониженням біоелектричної активності м'язів гомілки і факторами, які впливають на рівень нейропатичного болю і якістю життя існує тісний функціональний взаємозв'язок. Хворих з проявами аксонопатії, що поєднуються з демієлінізацією, слід віднести до групи ризику щодо розвитку функціональних порушень вищих відділів хребта і можливої інвалідизації. Заходи, передбачені програмою ерго- та фізичної терапії, позитивно впливають на зниження відчуття нейропатичного болю, підвищення якості життя, що підтверджується позитивною динамікою електрофізіологічних показників.
\end{abstract}

Ключові слова: алкогольна полінейропатія, якість життя, біль, електронейроміографія.

\section{Impact of physical rehabilitation by ergotherapy on patients with various types of polyneuropathies \\ O. V. Baskevych}

Vasyl Stefanyk Precarpathian National University, Ivano-Frankivsk, Ukraine

Abstract. Objective. To identify the main factors affecting the quality of life and the electrophysiological manifestations of alcoholic neuropathy and their changes after the application of methods of ergo-and physical therapy. Methods. Analysis of special scientific and methodological literature, clinical, laboratory and sociological methods, parametric and non-parametric statistics. Conclutions. There is a close functional relationship between the clinical manifestations of alcoholic polyneuropathy, asymmetric decrease of the bioelectric activity of the leg muscles and factors affecting the level of neuropathic pain and quality of life. Patients with manifestations of axonopathy, combined with demyelination, should be attributed to the risk group for the development of functional disorders of the higher parts of the spine and possible disability. Activities provided by the program of ergo- and physical therapy have a positive effect on reducing the feeling of neuropathic pain, improving the quality of life, as evidenced by the positive dynamics of electrophysiological indicators

Keywords: alcoholic neuropathy, quality of life, pain, electroneuromyography.

Постановка проблеми. Найбільш поширеним ускладненням з боку периферичної нервової системи у людей з розладами психіки та поведінки внаслідок вживання алкоголю $є$ алкогольна полінейропатія (АПНП) [1, 11]. За даними різних авторів її частота спостерігається в 30-70\% осіб з порушенням психіки і поведінки внаслідок вживання алкоголю [12, 14]. Захворювання прогресує протягом декількох місяців або навіть років і багато в чому залежить від кількості і якості вживаного алкоголю, віку, стажу та фрорми його вживання, супутніх захворювань (панкреатит, гепатит, цироз печінки, серцево-судинні захворювання), дієти [5, 13, 16].

За даними окремих авторів [6, 7, 19], АПНП проявляється у вигляді різних форм (гострої, підгострої або хронічної), трьома клініко-патогенетичними типами (токсичним, пов'язаним 3 дефіцитом тіаміну або змішаним), має виражені клінічні симптоми (з переважанням сенсорно-вегетативних або сенсорно-моторних розладів) і протікає у вигляді різних стадій: стадія 1, 
або асимптомна; стадія 2 - виявляється тільки суб'єктивними скаргами; стадія 3, або клінічно виражена з об'єктивним фрункціональним десріцитом [15].

Кожний тип АПНП має різну клінічну картину і механізми розвитку $[2,5,8,18]$. Невропатологи застосовують сучасні методи дослідження пацієнтів з АПНП, серед яких основним методом діагностики $\epsilon$ електронейроміографрія (ЕНМГ) [11, 14]. Цей інноваційний метод дослідження дозволяє визначити рівень, характер і ступінь ураження периферичних нервів [1]. Для найбільш поширеного, токсичного типу АПНП, характерна генералізована симетрична сенсорно-моторна, переважно дистальна аксонопатія 3 ознаками вторинної мієлінопатії.

Згідно з Міжнародною класифрікацією фрункціонування, обмеження життєдіяльності і здоров'я - МКФ-10 [10], діагностувати АПНП можна за наявності ЕНМГ змін принаймі в одному м'язі і у двох нервах при поєднанні із суб'єктивними симптомами та об'єктивними проявами захворювання за умови виключення ПНП іншої етіології, а також за наявності анамнестичних відомостей від хворого або його родичів про зловживання алкоголем.

Аналіз результатів останніх досліджень i публікацій. 3 огляду на багатофракторність механізмів розвитку $[5,6]$, поєднане ураження серцево-судинної системи, печінки та інших органів шлунково-кишкового тракту, наркологи проводять комплексну терапію АПНП [1-4]. Пацієнтів спостерігають невропатолог, терапевт, гепатолог, гастроентеролог та інші спеціалісти залежно від наявності того чи іншого ускладнення $[8,12,15]$. У більшості випадків прогноз при АПНП сприятливий, однак реабілітаційний період має досить значний часовий діапазон [17]. Це пояснюється тим, що неврологічні функції відновлюються відносно швидко, але у пацієнтів зберігаються залишкові явища ураження периферичних нервів, оскільки аксональна регенерація і відновлення колатеральних відростків нервових клітин протікають повільно.

Обов'язковою умовою ефективного лікування АПНП $є$ повна відмова від вживання спиртних напоїв, відновлення повноцінного збалансованого харчування з достатньою кількістю вітамінів і білка, фрізична реабілітація пацієнта $[1,3,12,17]$.

Комплексну терапію проводять ефективними лікарськими препаратами, які повинні мати мінімальний побічний і токсичний ефект $[11,14]$. При цьому, оскільки у цих пацієнтів завжди присутні виражені порушення грубої і дрібної моторики, особливу увагу приділяють заходам ерго- i фрізичної терапії $[15,17]$. Однак у зв'язку з тим що ці види терапії в Україні набувають широкого застосування тільки в останні роки, а спеціальні методики практично відсутні, нами були поставлені відповідні мета і завдання дослідження, що визначає актуальність даної роботи.

Зв'язок роботи 3 науковими планами, темами. Дослідження проведено відповідно до теми комплексної науково-дослідної роботи «Розробка пропозицій з оптимізації системи фрізичної терапії людей з розладами психіки і поведінки внаслідок вживання алкоголю», розробленої на кафредрі фрізичної терапії, ерготерапії і затвердженої в Прикарпатському національному університеті на 2019-2024 рр. Номер державної реєстрації $0116 \mathrm{U} 001419$.

Мета дослідження - виявити основні фрактори, що впливають на якість життя й електрофрізіологічні прояви алкогольної полінейропатії та їх зміни після застосування методів ерго- i фрізичної терапії.

Методи та організація дослідження. В роботі проаналізовано результати обстеження 25 пацієнтів з токсичними типами АПНП, які знаходилися на лікуванні в нарокологічному відділенні психоневрологічного диспансеру м. ІваноФранківська. Середній вік пацієнтів становить $32,5 \pm 2,8$ року; тривалість захворювання - від 1 міс. до 1,2 року.

Електронейроміографрічне дослідження проводили з використанням комп'ютерного комплексу «Нейро-ЭМГ-Микро» («Нейрософт», Росія). Досліджували м'язи, які входять до латерального (довгий малогомілковий м'яз) і дорзального (задній малогомілковий м'яз) міо-фрасціального кінематичного ланцюга (МФКЛ) правої $\mathrm{i}$ лівої гомілок.

Для діагностики АПНП використовували також голчасту ЕМГ. Вона дозволила кількісно оцінити параметри потенціалів дії рухових одиниць (ПДРО) і виявити ознаки денервації м'язів, які обумовлені ураженням аксона - потенціали фрібриляції, позитивні гострі хвилі.

Встановлення об'єктивних ознак больового синдрому та якість життя досліджували за допомогою анкет ВАШ і SF-36 [20]. Обстеження проводили двічі: до (контрольна група) і після (основна група) впровадження однорічного курсу ерго- і фрізичної терапії за розробленою нами програмою.

Працетерапію рекомендують для підвищення і збереження фрізичної працездатності, зміцнення м'язів і рухливості в суглобах, збільшення енерговитрат та недопущення збільшення маси тіла. Рекомендують роботи на свіжому повітрі, у 
садку, на присадибній ділянці, пиляння і рубання дров тощо [17].

В авторську програму входять різноманітні види масажу, робота в теплицях, пов'язана з доглядом за рослинами, що передбачає часті підйоми на носки і дотягування до рослин верхніх ярусів з подальшим згинанням тулуба і нижніх кінцівок для укладання плодів та овочів у продуктові ящики. Такі рухи позитивно впливають на гнучкість і стимулюють кровопостачання та лімфоввідтік у м'язах нижніх кінцівок.

Статистичну обробку даних здійснювали методами параметричної і непараметричної статистики за допомогою прикладного пакета програм «Statistika 6» (IBM SPSS Statistics for Microsoft Windows, USA) [9].

Результати дослідження та їх обговорення. Результати анкетування пацієнтів за анкетою SF-36 (табл. 1) вказують на те, що в зниженні рівня якості життя відіграють роль парестезії (відчуття «поколювання», «повзання мурашок», оніміння пальців стопи); періодичні судомні скорочення м'язів гомілки і стопи.

Майже у половини $(49,1 \%)$ пацієнтів з третьою стадією АПНП розвивається синдром «неспокійних» нижніх кінцівок. Як вказує Л. В. Веретило [5], його клінічну основу становить імперативне бажання рухати кінцівками внаслідок неприємних відчуттів, які більше проявляються вночі.

При цьому у всіх пацієнтів з тривалістю АПНП понад 8 міс. приєднуються дизестезії з гіперпатичним відтінком, невропатичні болі, які мають нестерпний «пекучий», «стріляючий» характер, що також посилюються вночі. 12,6 \% пацієнтів вказують, що зниження якості життя викликало поєднання сенсорних і вегетативно-трофрічних проявів у вигляді порушення потовиділення, набряклості стопи, гіперкератозу, гіперпігментації шкіри, трофічних виразок. Посилення вегетативної диссрункції призводить до порушення вегетативної іннервації внутрішніх органів, що суттєво погіршує розлади обміну речовин, викликані токсичною дією етанолу та його метаболітів. За даними Ю. Е. Разводовського [13], периферична вегетативна недостатність підвищує ризик раптової смерті пацієнтів внаслідок можливого розвитку безбольової фрорми інфаркту міокарда.

Ще одна група чинників, які істотно знижують якість життя цих пацієнтів, - наявність ортостатичної гіпотензії (зниженням артеріального тиску під час зміни положення тіла) - 18,9 \%; прискорене серцебиття стані спокою - 87,5\%; запори, що змінюються рідким випорожненням та інші розлади функції шлунка - 100,0 \%.
ТАБЛИЦЯ 1 - Кількісні показники і фактори, які викликають зниження рівня якості життя пацієнтів з алкогольною полінейропатією до і після впровадження авторської програми фізичної терапії (\%, n = 25)

\begin{tabular}{|c|l|c|c|}
\hline № 3/n & \multicolumn{1}{|c|}{ Показники } & До & Після \\
\hline 1 & Парестезії & 34,2 & 10,4 \\
\hline 2 & Судоми & 12,5 & 10,1 \\
\hline 3 & «Неспокійні ноги» & 49,1 & 23,5 \\
\hline 4 & Нейропатичні болі & 89,2 & 12,2 \\
\hline 5 & Посилене потовиділення & 90,1 & 30,3 \\
\hline 6 & Набряк стопи і гомілки & 75,3 & 4,5 \\
\hline 7 & Гіперкератоз & 45,2 & 34,2 \\
\hline 8 & Гіперпігментації & 16,7 & 16,6 \\
\hline 9 & Трофрічні виразки & 10,1 & 9,8 \\
\hline 10 & Ортостатична гіпотензія & 42,1 & 23,4 \\
\hline 11 & Тахікардія & 100,0 & 43,5 \\
\hline 12 & Розлади органів шлунково- & 98,2 & 65,8 \\
\hline 13 & кишкового тракту & & \\
\hline 14 & Гіпотрофрія м'язів & 97,1 & 82,1 \\
\hline 15 & Пруднощі з ходьбою & 78,2 & 16,5 \\
\hline
\end{tabular}

Усі пацієнти вказали, що до надходження на стаціонарне лікування симптоми АПНП у них прогресували протягом декількох місяців або років. Симптоми захворювання починалися з дистальних відділів нижніх кінцівок, поширювалися на проксимальні відділи ніг, нижні відділи тулуба, у більш важких випадках - на верхні кінцівки. При даній клінічній фрормі сенсорний дефект переважає над моторним. У половини пацієнтів навіть за тривалого перебігу хвороби рухових порушень не виникає. у $33,3 \%$ хворих протягом 2-3 міс. від початку захворювання приєдналися слабкість у розгиначах стопи і пальців, розвинулася гіпотрофрія (зменшення об'єму) м'язів, що проявлялося слабкістю в дистальних, а пізніше - у проксимальних відділах нижньої кінцівки і кистях, ще у 20,4 \% виникли труднощі ходьби з деякими порушеннями координаційних здібностей. Така послідовність розвитку симптомокомплексу АПНП може бути пов'язана із закономірностями розвитку і хронологією розвитку аксоно- і мієлінопатії $[5,6]$.

Під час об'єктивного дослідження виявлено порушення больової і температурної чутливості за поліневропатичним типом [11] у вигляді зниження або підвищення чутливості. У деяких випадках розвиваються ознаки аллодинії (біль внаслідок впливу подразників, які в звичайних умовах її не викликають) [12]. На ранніх стадіях захворювання у 23,1\% пацієнтів згасає, а потім зникає ахілловий ресрлекс. У 10,2 \% пацієнтів, які не звертались за кваліфрікованою допомогою до надходження в стаціонар, прогресування патологічного процесу призвело до зниження колінних i сухожильних рефлексів на верхніх кінцівках. 

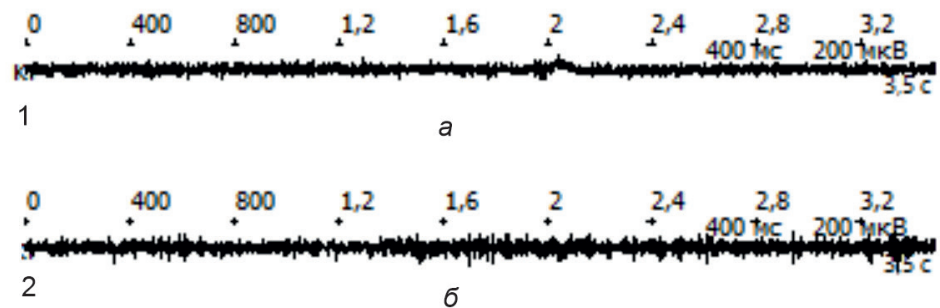

Рисунок 1 - Інтерференційна електроміограма м'язів гомілки, які входять до складу переднього (a) и заднього (б) міофасціального кінематичного ланцюга, пацієнта 32 років при алкогольній полінейропатії:

1 - передній великогомілковий м'яз, глибокий малогомілковий нерв, $\mathrm{L}_{4}-\mathrm{S}_{1} ; 2$ - задній великогомілковий м'яз, великогомілковий нерв, $L_{5}-S_{2}$

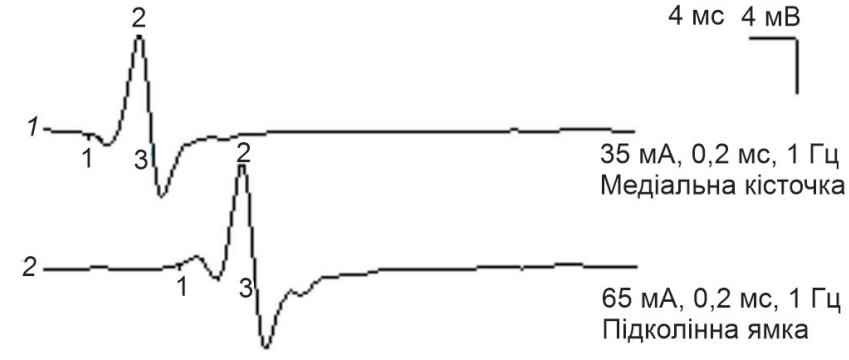

Рисунок 2 - Латентний період та швидкість поширення збудження (правий литковий м'яз, великогомілковий нерв, $\mathrm{L}_{4-5}-\mathrm{S}_{2}$ ) по чутливих (1) і рухових (2) нервових волокнах у пацієнта 35 років з хронічною алкогольною полінейропатією

У $33,4 \%$ пацієнтів під час хронічного перебігу АПНП (понад 8 міс.), розвивається моторний дефріцит, який лежить в основі інвалідизації даних пацієнтів $[5,8,14]$ і проявляється симетричними, в основному дистальними, парезами за рахунок переважного ураження м'язів-розгиначів стопи і кисті, що на ранньому етапі проявляється порушенням здатності ходити на носках і п'ятах. Поступово парези поширюються у висхідному напрямку, з розвитком вираженого нижнього парапарезу.

Характерним патерном (рис. 1, $a, 6)$ порушення тонусу м'язів $€$ не тільки зниження загальної активності всіх м'язів стопи і гомілки, а й явно виражений дисбаланс активності між переднім і заднім міофасціальними кінематичними ланцюгами (МФКЛ).

У $90,2 \%$ пацієнтів з АПНП характерна генералізована симетрична сенсорно-моторна, переважно дистальна, аксонопатія з ознаками вторинної мієлінопатії, що проявляється зниженням амплітуди потенціалів дії рухових одиниць. Це відображає ураження осьового циліндра нервового волокна - аксонопатію [6]. Відзначається (рис. 2) зменшення швидкості поширення збудження по чутливих і рухових волокнах усіх перифреричних нервів кінцівок, що $є$ ознакою мієлінопатії [14].

Зазначені зміни можуть спостерігатися у пацієнтів, які мають мало виражені клінічні ознаки

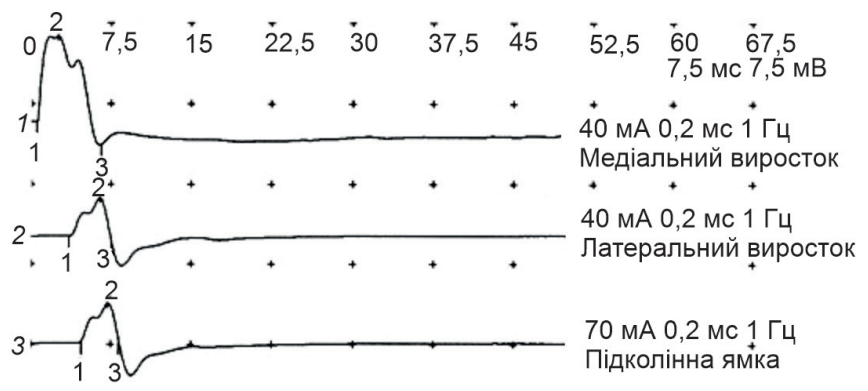

Рисунок 3 - Латентний період і швидкість поширення збудження (правий литковий м'яз, великогомілковий нерв, $\left.\mathrm{L}_{4-5},-\mathrm{S}_{1}\right)$ по чутливих $(1)$ і рухових $(2,3)$ нервових волокнах у пацієнта 29 років з асимптомною алкогольною полінейропатією

АПНП, але виявляються у $90,0 \%$ випадків під час ЕНМГ-дослідження (рис. 3). Також досить часто виявляються ознаки денервації, які корелюють із ступенем вираженості клінічної картини АПНП. При цьому реєструвалися потенціали фрібриляцій високої амплітуди, але короткої тривалості, які мають хоч і чіткий, але непостійний ритм (рис. 4).

Такі зміни у м'язах нижніх кінцівок відіграють важливу роль у порушенні поступального балансу та координації рухів і підвищують ризик мимовільного падіння таких пацієнтів [12]. У зв'язку з цим, окремі автори пропонують проводити додаткове обстеження з використанням стабілографрії

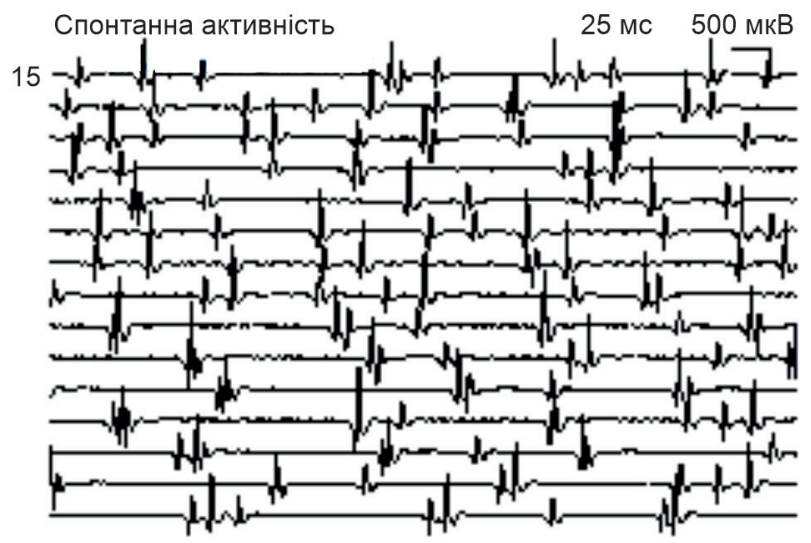

Рисунок 4 - Потенціали спонтанної активності у литковому м'язі пацієнта 40 років з алкогольною полінейропатією до лікування 


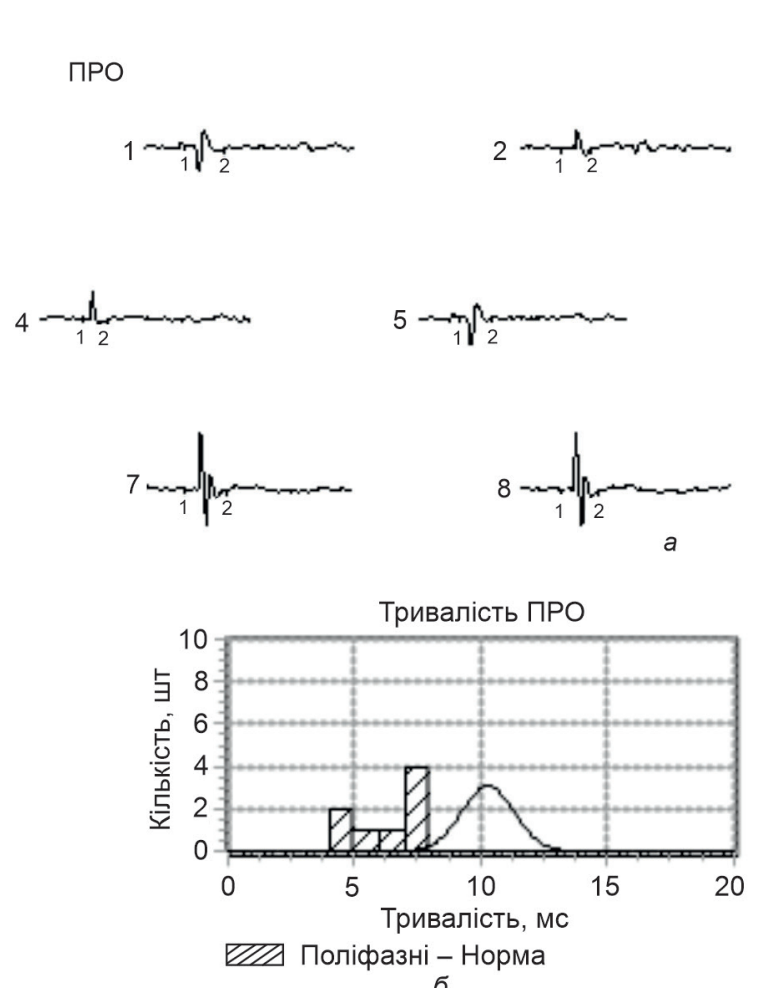

6
$10 \mathrm{mc} 200 \mathrm{mkB}$

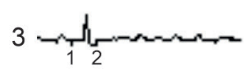

6
Рисунок 5 - Якісні (a): 1-8 реєстрація потенціалів рухових одиниць 3 різних волокон литкового м'яза; кількісні $(\sigma$, в) ЕМГ-показники литкового м'яза пацієнта 40 років $з$ алкогольною полінейропатією до лікування; ПРО - потенціал рухових одиниць
[14], оскільки порушення коливальних рухів у фронтальній площині $€$ патогномонічною ознакою підвищеного ризику падіння [21].

У більшості пацієнтів активність введення електрода становить в середньому 1,68 \pm 0,001 с, тоді як амплітуда ПДРО - 157,5 \pm 2,07 мкВ, а їх тривалість у литковому м'язі - в середньому 8,4 \pm 0,62 мс.

На рисунку 5 представлено приклади ПДРО до початку комплексного лікування АПНП. Як видно з представлених даних, реєструвалися переважно ПДРО зменшеного типу.

Проведений річний курс ерго- і фрізичної терапії позитивно вплинув на пацієнтів з АПНП. Про це свідчать результати анкетування за SF-36 (див. табл. 1). Пацієнти вказують на зменшення больових відчуттів (45,0 \%), повну відсутність болю $(23,0 \%)$, ще 22,0 \% відмічають тільки періодичні болі, інші 10,0 \% вказали на відсутність будь-якого покращення стосовно больових відчуттів. Треба відмітити, що серед останніх більшість пацієнтів $(90,0$ \%), в яких діагностовано третій ступінь важкості АПНП тривалістю понад 12 міс. За даними багатьох авторів [3] механізм болю при АПНП має складний характер і при хронічних фрормах вимагає не тільки інтенсивного, а й тривалого медикаментозного лікування $[4,8]$. На нашу думку, такі пацієнти вимагають застосування додаткових засобів фрізіотерапії, ЛФК, акупунктури тощо.

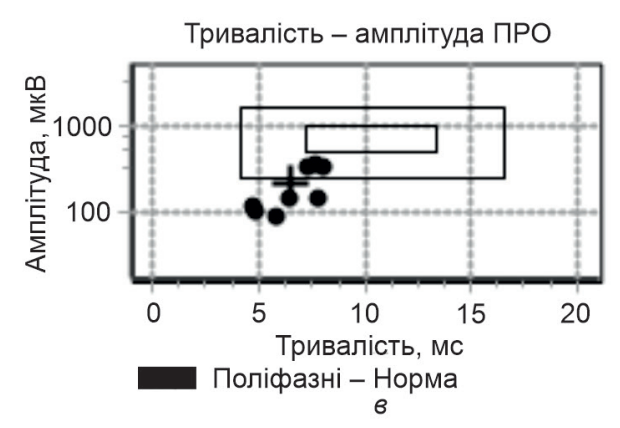

За даними аналізу шкали за протоколом ВАШ у 35,0 \% пацієнтів інтенсивність болю знизалась з 4 до 2 балів, у 32,0\% - з 4 до 1 бала, ще у $23,0 \% 34$ до 0 балів.

Впровадження у практику авторської програми сприяло зменшенню прояву парестезії, оніміння пальців стопи, періодичних судом у м'язах гомілки і стопи у загальному багатофракторному ряду чинників, що знижували якість життя цих пацієнтів до початку ерго- і фрізичної терапії. При цьому значно зменшилась кількість пацієнтів (16,7 проти 44,0% до лікування) з синдромом «неспокійних» нижніх кінцівок. 3 12,6 до 5,3 \% знизилась кількість пацієнтів із вегетативним дисбалансом.

Проведення повторного ЕМГ-обстеження засвідчило суттєве покращення стану периферійного нервово-м'язового апарату нижніх кінцівок (рис. 6).

Це проявляється збільшенням амплітуди Н- та М-відповіді, зменшенням латентного періоду Нта М-хвилі, збільшенням кількості та амплітуди рухових одиниць зі зміщенням гістограми розподілу в центр і дещо вправо.

Основні показники математико-статистичної обробки даних про ЕМГ-показники залежно від етапу лікування представлені в таблиці 2.

Про позитивну динаміку змін у стані периферійного нервово-м'язового апарату скелетних м'язів нижньої кінцівки після проведеного комплексного лікування свідчать також показники 


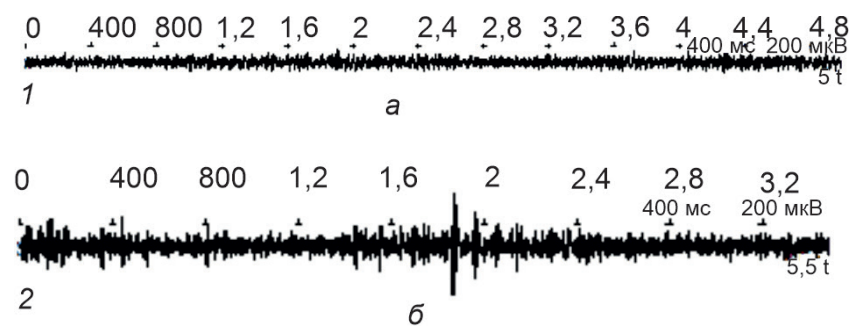

Рисунок 6 - Інтерференційна електроміограма м'язів гомілки, які входять до складу переднього $(a)$ и заднього (б) міофасціального кінематичного ланцюга пацієнта 32 років після проведеної комплексної медикаментозної та ергофрізичної терапії:

1 - передній великогомілковий м'яз, глибокий малогомілковий нерв, $\mathrm{L}_{4}-\mathrm{S}_{1} ; 2$ - довгий м'яз-згинач великого пальця, великогомілковий нерв, $\mathrm{L}_{5}-\mathrm{S}_{2}$

голчастої ЕМГ. При цьому активність введення електрода зменшується і становить у середньому $1,19 \pm 0,001 \mathrm{c}$.

Виявлено тільки ознаки денерваційно-реінерваційного процесу, ступінь вираженості якого корелювала зі ступенем покращення даних анкетування якості життя і анкети ВАШ та загального клічного стану пацієнтів. Тільки у п'яти хворих у м'язах гомілки реєструвалася спонтанна активність у вигляді окремих потенціалів фрібриляцій різної амплітуди: від 10 до 50 мкВ і тривалістю від 1 до 5 мс. Вони мають нечіткий характер і непостійний ритм (рис. 7).

Потенціали дії рухових одиниць мають хоча неправильну форму, проте спостерігається збереження послідовності окремих фраз. Амплітуда всіх ПДРО перевищує 630 мкВ (рис. 8, a), а середнє значення становить $502,5 \pm 3,17$ мкВ.

При цьому у трьох пацієнтів спостерігалось більше чотирьох ПДРО з амплітудою 780,0 мкВ.

ТАБЛИЦЯ 2 - Результати електроміографічного обстеження великогомілкового нерва пацієнтів до і після комплексної терапії алкогольної полінейропатії (M $\pm \mathrm{m}, \mathrm{n}=25)$

\begin{tabular}{|c|l|c|c|}
\hline $\begin{array}{c}\text { № } \\
\text { 3/n }\end{array}$ & \multicolumn{1}{|c|}{ Показник } & До & Після \\
\hline 1 & Амплітуда М-відповіді, мВ & $6,7 \pm 1,06^{*}$ & $12,15 \pm 1,23$ \\
\hline 2 & $\begin{array}{l}\text { Резидуальна латентність, } \\
\text { мс }\end{array}$ & $1,6 \pm 0,04$ & $1,8 \pm 0,02$ \\
\hline 3 & $\begin{array}{l}\text { Швидкість проведения } \\
\text { імпульсу на дистальному } \\
\text { відрізку, м·с }{ }^{-1}\end{array}$ & $35,5 \pm 2,21^{*}$ & $51,2 \pm 2,64$ \\
\hline 4 & $\begin{array}{l}\text { Амплітуда сенсорної від- } \\
\text { повіді, мкВ }\end{array}$ & $2,6 \pm 0,02^{*}$ & $9,1 \pm 0,35$ \\
\hline 5 & $\begin{array}{l}\text { Швидкість проведения ім- } \\
\text { пульсу на проксимальному } \\
\text { відрізку, м·с }{ }^{-1}\end{array}$ & $39,1 \pm 2,89^{*}$ & $55,3 \pm 2,17$ \\
\hline
\end{tabular}

* Статистично вірогідна різниця при $\mathrm{p}<0,05$.

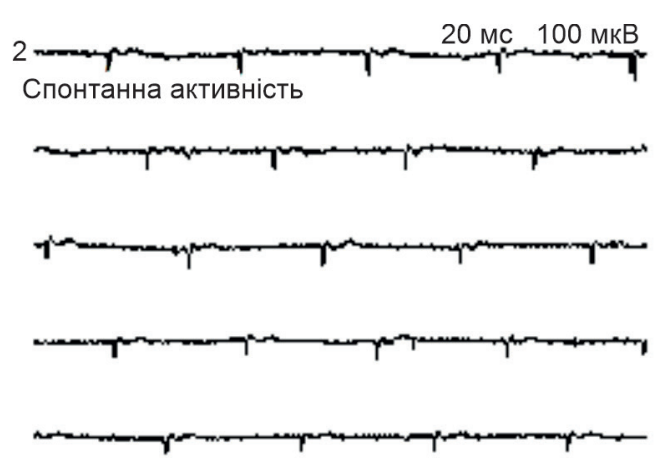

Рисунок 7 - Потенціали спонтанної активності у литковому м'язі пацієнта 40 років після комплексного лікування

Гістограма розподілу ПДРО за тривалістю має вигляд нормального розподілу, при якому мінімальна і максимальна тривалість окремих ПДРО не виходить за межі $\pm 20,2 \%$ (критичне значення $\pm 30,0 \%)$ від нормативного показника середньої величини тривалості ПДРО (рис. 8, б).

Цей показник порівняно з показниками до ерготерапії і фрізичної терапії зменшується в середньому на $14,5 \pm 0,63 \%(p<0,05)$ і становить у середньому 12,6 мс.

Гістограма розподілу ПДРО за їх тривалістю зсунута вправо за рахунок збільшення розмірів рухових одиниць (див. рис. 8,6 ). У середньому на 8,8 $\pm 0,12 \%$ зменшується кількість поліфазних ПДРО і становить у середньому $6,7 \pm 0,25 \%$ від усіх зареєстрованих у литковому м'язі ПДРО, хоча вони все ще перевищують нормативні показники (до 5,0 \%).

Висновки. Дані, отримані в ході проведення дослідження, підтверджують тісний фрункціональний взаємозв'язок асиметричного пониження біоелектричної активності м'язів гомілки 3 клінічними проявами алкогольної полінейропатії. Поява ЕНМГ-симптомів свідчить про розвиток у даної категорії хворих функціональних порушень перифреричного нервового апарату на фоні зниження якості життя і вираженого больового синдрому. Хворих з проявами аксонопатії, що поєднуються з демієлінізацією, слід віднести до групи ризику щодо розвитку функціональних порушень вищих відділів хребта і можливої інвалідизації. Для своєчасного виявлення фрункціональних порушень периферичного відділу нервової системи у хворих з АПНП необхідно проводити поверхневу електроміографію скелетних м'язів на початковому та кінцевому етапі лікування і після фрізичної реабілітації. 


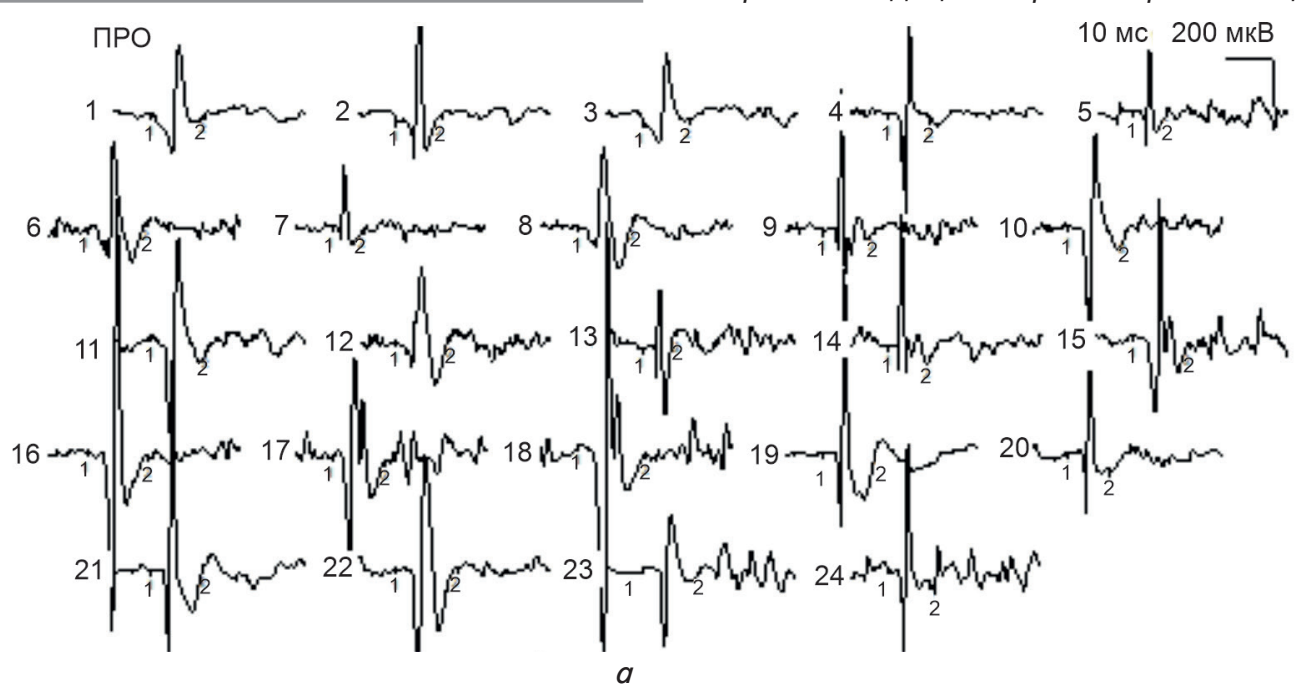

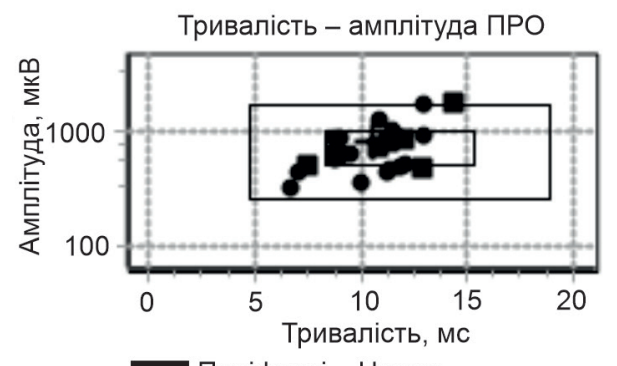

Поліфазні - Норма б

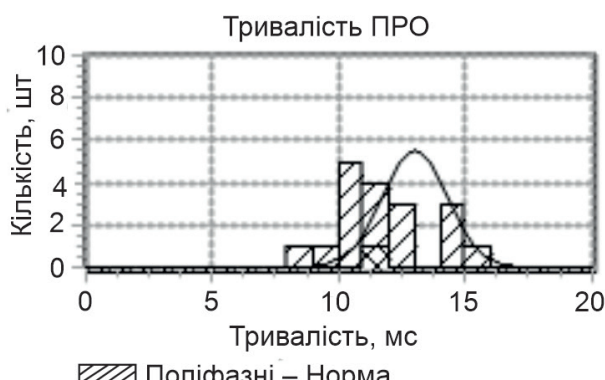

B
Рисунок 8 - Якісні $($ a): 1-24 - реєстрація потенціалів рухових одиниць з волокон литкового м'яза; кількісні $(б$, В) ЕМГ-показники литкового м'яза пацієнта 40 років після комплексної терапії алкогольної полінейропатії; ПРО - потенціал рухових одиниць
Заходи, передбачені програмою ерго- та фрізичної терапії, позитивно впливають на зниження відчуття нейропатичного болю, підвищення якості життя, що підтверджується позитивною динамікою електрофрізіологічних показників.

\section{Література}

1. Альтшулер ВБ, Кравченко СЛ, Силаева ВВ. Полиневропатия в клинике алкоголизма, ее место и лечение [Polyneuropathy in the clinic of alcoholism, its place and treatment]. Психиатрия и психофрармакотерапия. 2013;15(2): 23-25.

2. Анисимова НА, Куташов ВА. Современная терапия синдрома отмены алкоголя [Modern therapy of alcoho withdrawal]. Центральный научный вестник. 2016;14: 4-5.

3. Батуева ЕА, Кайгородова НБ, Каракулова ЮВ. Влияние нейротрофической терапии на нейропатическую боль и психовегетативный статус больных диабетической нейропатией [Impact of neurotrophic therapy on neuropathic pain and psycho-vegetative status of patients with diabetic neuropathy]. Российский журнал боли. 2011;2: 46.

4. Бойко АН, Батышева ТТ, Костенко ЕВ, Пивоварчик ЕМ. Нейродикловит: возможность применения у пациентов с болью в спине [Neurodiclovitis: the possibility of use in patients with back pain]. Фарматека. 2010;7: 63-68.

5. Веретило ЛВ, Исмаилов АМ, Лисинкер ЛН, Хозова АА. Злокачественный алкоголизм: особенности формирования и клинические варианты [Malignant alcoholism: features of the formation and clinical options]. Наркология. 2014;13(2): 42-51.
Перспективи подальших досліджень полягають у вивченні можливості використання електронейроміографічних показників у встановленні рівня реабілітаційного потенціалу людей з порушенням психіки і поведінки внаслідок вживання алкоголю.

6. Зобин МЛ. Алкогольная зависимость как хроническое рецидивирующее заболевание - универсальная концепция? [Alcohol addiction as a chronic recurrent disease - a universal concept?]. Наркология. 2013;12(5): 71-80.

7. Китаев РБ, Куташов ВА, Шульга АС. Абстинентное состояние с делирием, вызванное употреблением алкоголя. Клиника. Диагностика. Лечение [Abstinence with delirium caused by alcohol. Clinic. Diagnostics. Treatment]. Центральный научный вестник. 2017;20(3): 21-23.

8. Когтева ЕС, Куташов ВА, Шульга АС. К вопросу о медикаментозном лечении алкоголизма [On the issue of drug treatment of alcoholism]. Центральный научный вестник. 2016;17(1): 13-15.

9. Медик ВА, Токмачев МС. Математическая статистика в медицине [Mathematical statistics in medicine]. Москва: Финансы и статистика; 2007. 800 c.

10. МКБ-10 (Международная классификация болезней) [MKB-10 (International Classification of Diseases)]. Ел. ресурс: http://www.who.int/classfication/icf

11. Морозова ОГ. Полинейропатии в соматической практике [Polyneuropathy in somatic practice]. Внутренняя медицина. 2007;4(4): 37-9. 
12. Портнов АА, Пятницкая ИН. Алкоголизм: Руководство для врачей [Alcoholism: A Guide for Doctors]. Москва: Мегаполис; 2012. 576 с.

13. Разводовский ЮЕ. Алкоголь как фрактор риска сердечно-сосудистой смертности [Alcohol as a risk factor fo cardiovascular mortality]. Наркология. 2013;12(2): 38-42.

14. Ржевская НК, Куташов ВА. Клиника и диагностика алкогольных психозов [Clinic and diagnosis of alcoholic psychosis]. Центральный научный вестник. 2016;13(1): 31-34.

15. Ржевская НК, Куташов ВА, Ульянова ОВ. Современный подход к психотерапевтическому лечению алкоголизма [Modern approach to psychotherapeutic treatment of alcoholism]. Центральный научный вестник. 2016;13(1): 29-31.

16. Ржевская НК, Куташов ВА. Возрастные особенности алкоголизма [Age characteristics of alcoholism]. Центральный научный вестник. 2016;16(1): 32-34.

hejlion@gmail.com
17. Ржевская НК, Куташов ВА. Реабилитация больных с хроническим алкоголизмом [Rehabilitation of patients with chronic alcoholism]. Центральный научный вестник. 2016;15(1): 29-31.

18. Ржевская НК, Куташов ВА. Современные подходы к лечению алкогольных психозов [Modern approaches to the treatment of alcoholic psychosis]. Центральный научный вестник. 2016;14(1): 46-8.

19. Щербак EA, Куташов ВА, Сиволап ЮП. Депрессия и алкоголизм: клинико-социальные взаимоотношения [Depression and alcoholism: clinical and social relationships]. Москва: РИТМ; 2018. 177 с.

20. Leppert W, Forycka M. Assessment of pain and quality of life in cancer patients. Gastroenterol. Pol. 2011;18(3): 127-131.

21. Petrella M, Neves TM, Reis JG, Gomes MM. Postural control parameters in elderly male fallers and non-fallers diagnosed or not with knee osteoarthritis. Sociadade Brazilieira de Reumatologia. 2012;52(4): 512-17.

Надійшла 5.06.2019 